\title{
Unique and fragile diversity emerges from Brazilian caves - two new amphibious species of Xangoniscus Campos-Filho, Araujo \& Taiti, 2014 (Oniscidea, Styloniscidae) from Serra do Ramalho karst area, state of Bahia, Brazil
}

Ivanklin S. Campos-Filho', Jéssica S. Gallo², Jonas E. Gallão², Dayana F. Torres², Lília Horta ${ }^{3}$, Yesenia M. Carpio-Díaz ${ }^{4}$ Carlos M. López-Orozco ${ }^{4}$, Ricardo Borja-Arrieta ${ }^{4}$, José O. Aguiar ${ }^{5}$, Maria E. Bichuette ${ }^{2,3}$

I Department of Biological Sciences, University of Cyprus, Lefkosia (Nicosia), Cyprus 2 Laboratório de Estudos Subterrâneos, Universidade Federal de São Carlos, São Carlos, São Paulo, Brazil 3 Grupo Bambui de Pesquisas Espeleológicas, Belo Horizonte, Minas Gerais, Brazil 4 Grupo de Investigación en Biología Descriptiva y Aplicada, Programa de Biología, Universidad de Cartagena, Campus San Pablo, Cartagena de Indias, Colombia 5 Programa de Pós-Graduação em Engenharia e Gestão de Recursos Naturais, Universidade Federal de Campina Grande, Campina Grande, Paraíba, Brazil

Corresponding author: Ivanklin Soares Campos-Filho (ivanklin.filho@gmail.com)

Academiceditor:MatthewL.Niemiller|Received24September2021|Accepted23December2021|Published 10January 2022

http://zoobank.org/5C413E74-53FA-4ABO-B4CB-B6A332C83030

Citation: Campos-Filho IS, Gallo JS, Gallão JE, Torres DF, Horta L, Carpio-Díaz YM, López-Orozco CM, BorjaArrieta R, Aguiar JO, Bichuette ME (2022) Unique and fragile diversity emerges from Brazilian caves - two new amphibious species of Xangoniscus Campos-Filho, Araujo \& Taiti, 2014 (Oniscidea, Styloniscidae) from Serra do Ramalho karst area, state of Bahia, Brazil. Subterranean Biology 42: 1-22. https://doi.org/10.3897/subtbiol.42.75725

\begin{abstract}
Two new troglobitic species of Xangoniscus are described from two caves of Serra do Ramalho karst area, Bambuí geomorphological group, state of Bahia. Xangoniscus lapaensis sp. nov. is described from Gruna Boca da Lapa cave, and X. loboi sp. nov. from Gruna da Pingueira II cave. Both species are blind and depigmented and show amphibious habits, as observed for all species of Xangoniscus described until now. Xangoniscus lapaensis sp. nov. occurs in travertine pools fed by water of the upper aquifer, and $X$. loboi sp. nov. occurs in a small stream, an upper vadose tributary. Both species occur in fragile microhabitats. Ecological and behavioral data, conservation remarks, and IUCN conservation assessments are included to provide background data for conservation efforts in this unique karst area.
\end{abstract}

\section{Keywords}

Bambuí geomorphological group, Limestone, Terrestrial isopods, Troglobitic, Upper Aquifer

Copyright Ivanklin Soares Campos-Filho et al. This is an open access article distributed under the terms of the Creative Commons Attribution License (CC BY 4.0), which permits unrestricted use, distribution, and reproduction in any medium, provided the original author and source are credited. 


\section{Introduction}

Terrestrial isopods (Oniscidea) are the only crustacean lineage completely adapted to the terrestrial way of life (Hornung 2011; Richardson and Araujo 2015; Taiti 2018). The group occurs in almost all kinds of terrestrial habitats, including caves (Schmalfuss 2003; Taiti 2004). Oniscidea comprises about 4,000 species distributed in more than 500 genera and 38 families (Javidkar et al. 2015, 2017; Sfenthourakis and Taiti 2015; Dimitriou et al. 2019; Campos-Filho and Taiti 2021; WoRMS 2021).

Terrestrial isopods are one of the most representative taxa in the Brazilian subterranean environments, probably due to the special environmental conditions, such as high humidity, substrate heterogeneity, and absence of specialized predators (Fernandes et al. 2016, 2019). To date, about 210 species are known from Brazil, 70 of which, belonging to the families Styloniscidae, Philosciidae, Scleropactidae, Dubioniscidae, Platyarthridae, Porcellionidae, Armadillidae, Pudeoniscidae, and Armadillidiidae, are recorded from Brazilian caves. Thirty-two taxa are considered to be troglobites (obligatory and restricted to caves), several are troglophiles (facultative cave species), and some species are possibly trogloxenes (Souza et al. 2011; Campos-Filho et al. 2014, 2015a, 2015b, 2016, 2017a, 2017b, 2018, 2019, 2020; Bastos-Pereira et al. 2017; Fernandes et al. 2018, 2019; Cardoso et al. 2020a, $2020 \mathrm{~b}, 2021)$. The species placed into the last two categories are difficult to assign into a correct subterranean category due to the scarcity of distribution data outside caves.

Among the troglobitic representatives of the Brazilian Oniscidea, 12 species have an amphibious way of life, all in the Styloniscidae: Chaimowiczia uai Cardoso, BastosPereira, Souza \& Ferreira, 2021, C. tatus Cardoso, Bastos-Pereira, Souza \& Ferreira, 2021, Iuiuniscus iuiuensis Souza, Ferreira \& Senna, 2015, Spelunconiscus castroi Campos-Filho, Araujo \& Taiti, 2014, Xangoniscus aganju Campos-Filho, Araujo \& Taiti, 2014, X. ceci Cardoso, Bastos-Pereira, Souza \& Ferreira, 2020, X. dagua Cardoso, Bastos-Pereira, Souza \& Ferreira, 2020, X. ibiracatuensis Cardoso, Bastos-Pereira, Souza \& Ferreira, 2020, X. itacarambiensis Bastos-Pereira, Souza \& Ferreira, 2017, X. lundi Cardoso, Bastos-Pereira, Souza \& Ferreira, 2020, X. odara Campos-Filho, Bichuette \& Taiti, 2016, and X. santinhoi Cardoso, Bastos-Pereira, Souza \& Ferreira, 2020.

The present work describes two new species of Xangoniscus from the Serra do Ramalho karst area, state of Bahia, both occurring in special microhabitats, namely the upper aquifers fed by infiltration of water in the limestone rock. Moreover, aspects of their ecology and natural history, as well as conservation remarks about this particular and unique fauna and the region of Serra do Ramalho are given.

\section{Materials and methods}

\section{Collections and taxonomy}

Specimens of Xangoniscus were collected by hand with the aid of tweezers and brushes. Specimens were stored in $70 \%$ and $100 \%$ ethanol. Descriptions are based on morphological characters with the use of micropreparations in Hoyer's 
medium (Anderson 1954). For each new species, the diagnosis, type material, description, etymology, and remarks are given. The habitus images were taken with the stereomicroscope model Motic SMZ-168 and the Celestron Microcapture Pro. The photographs were prepared with Adobe Photoshop CC Lite (v. 14.2.1). The appendages were illustrated with the aid of a camera lucida mounted on a $\mathrm{CH} 2$ Olympus microscope. The final illustrations were prepared using the software GIMP (v. 2.8) according to the method proposed by Montesanto $(2015,2016)$.

Maps were produced highlighting the caves where both Xangoniscus species occur, as well the hydrological attributes and pressures of economic activities in the region, representing impacts to the cave fauna. The distribution map was constructed with QGIS software (v. 3.18.1) and was edited in PowerPoint Microsoft 365 (v. 2108).

The material is deposited in the scientific collection of cave fauna of the Laboratório de Estudos Subterrâneos (LES), Universidade Federal de São Carlos, São Carlos, Brazil (Curator: Maria E. Bichuette).

\section{Ecological and behavioral study}

Both populations were studied in one field trip in October 2020, during the dry-wet season transition. Specimens were sampled ad libitum (sensu Altmann 1974; Martin and Bateson 2007). In addition, direct observations of other ecological and behavior data were recorded including reproductive aspects, movement, and microhabitat preferences as well as course estimations of abundance and population density. Microhabitat data included cave zone, type of substrate, depth, water current, and physicochemical variables $-\mathrm{pH}$ and temperature.

To assess population parameters (density and size of the population), the individuals were counted along microhabitat inside caves, and measurements (such as length, width, and total area) of the occurrence sites were taken. The population parameters were calculated by dividing the number of individuals observed by area of the occurrence site. Photographs and short videos were taken to document the behavior of both species and the influence of the microhabitat on their distribution in the caves (see Supplementary Online Material).

\section{Study area}

\section{Serra do Ramalho karst area, State of Bahia, northeastern Brazil}

The Serra do Ramalho karst area, southwestern State of Bahia, is located within the Bambuí geomorphological group, which hosts a high number of caves, mostly without legal protection. Some caves within this karst region extend for more than $15 \mathrm{~km}$, developing huge cave systems (Rubbioli et al. 2019). The Serra do Ramalho karst area comprises the municipalities of Coribe, Feira da Mata, Carinhanha, and Serra do Ramalho, and plateaus are made of limestone belonging to the Bambuí geomorphologic group. Moreover, the limestone in the region forms outcrops that extend parallel to the São Francisco River (Auler et al. 2001; 
Rubbioli et al. 2019). According to Köppen criteria, the region has a tropical dry climate (=semiarid) ("Aw"), with annual precipitation of about $640 \mathrm{~mm}$ (Beck et al. 2018, 2020). Subterranean waters are mainly exploited for human consumption (Belda et al. 2014; Rubbioli et al. 2019). Surrounding vegetation consists of "Caatinga" composed of mesophytic and xeromorphic forests interspersed with "Cerrado" (savannah-like vegetation). The two new species described herein occur in two caves of the Serra do Ramalho karst area within the São Francisco River basin (Figs 1-3). Figures 2 and 3 show details of the habitat of the new Xangoniscus species. Human pressures related to common economic activities in the region (mining and land use), and typical vegetation are shown in Fig. 1. Currently, mining and land use pressures represent a great threat to habitat of cave species in the region.

\section{Results}

\section{Family Styloniscidae Vandel, 1952}

\section{Genus Xangoniscus Campos-Filho, Araujo \& Taiti, 2014}

Type species. Xangoniscus aganju Campos-Filho, Araujo \& Taiti, 2014, by original designation.

\section{Xangoniscus lapaensis Campos-Filho, Gallo \& Bichuette, sp. nov.} http://zoobank.org/855DC7C6-D196-4B19-8340-18DB358A7277 Figures 1, 2, 4-7

Type locality. Bahia, Feira da Mata, Gruna Boca da Lapa cave (1356'46.4"S, $\left.44^{\circ} 11^{\prime} 12.0^{\prime \prime} \mathrm{W}\right)$.

Type material. Holotype male (LES 27734), Bahia, Feira da Mata, Gruna Boca da Lapa cave, 15 October 2020, leg. ME Bichuette, DF Torres, JS Gallo, L Senna-Horta \& JE Gallão. Paratypes 1 male (parts in slides), 2 females (LES 27735); 1 male, 3 females (one female with parts in slides) (LES 27736), same data as holotype.

Description. Body length: ơ $8.0 \mathrm{~mm}, q 9.3 \mathrm{~mm}$. Body unpigmented, slightly robust, lateral sides slightly convex (Figs 2C, D, 4A-C). Dorsal surface smooth with scattered fringed scale setae (Fig. 5A). Pereonite 1 epimera with distal corners slightly developed frontwards, not surpassing cephalon, posterior corners right-angled; pereonite 2-4 epimera gradually directed backwards, posterior corners progressively more acute; pleon slightly narrower than pereon, pleonites 3-5 epimera well-developed and falciform (Figs 4B, 5C). Cephalon (Figs 4C, 5B) with large quadrangular antennary lobes; vertex with lateral depression to fit antennae when extended backwards, profrons with V-shaped suprantennal line; eyes absent. Telson (Fig. 5C) with well pronounced concave sides and broadly rounded apex. Antennula (Fig. 5D) of three articles, medial and distal articles subequal in length, second article bearing one long seta on inner margin, distal article with two long apical aesthetascs. Antenna (Fig. 5E) with fifth article of peduncle longer than flagellum; flagellum of three articles, first article longest, distal 


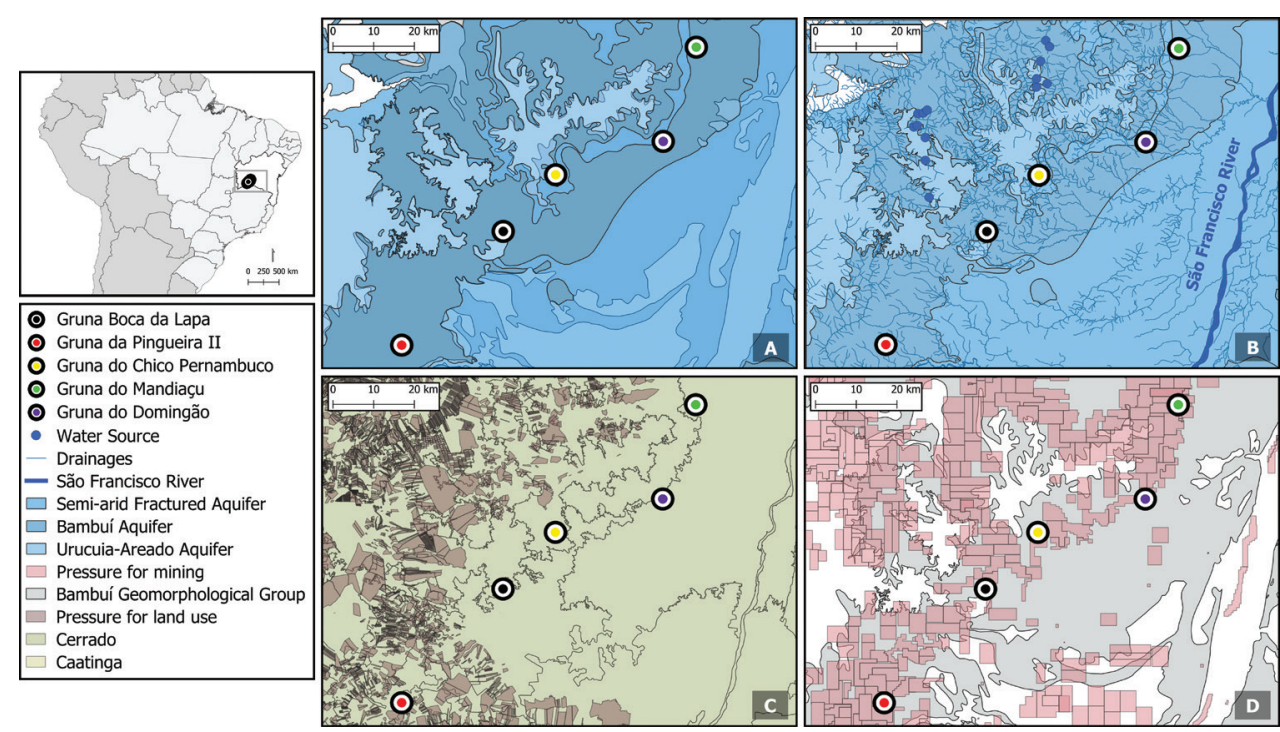

Figure I. Maps of Serra do Ramalho karst area, State of Bahia, northeastern Brazil A limestone outcrops of the Bambuí geomorphological group, Fraturado and Urucuia-Areado aquifer systems showing the typelocalities (caves) of X. lapaensis sp. nov. and X. loboi sp. nov. B headwaters and São Francisco river basin C pressure for land use showing human-caused alterations $\mathbf{D}$ pressure for mining activities.

article bearing tuft of free sensilla. Left mandible (Fig. 5F) with two penicils, right mandible (Fig. 5G) with one penicil and lacinia mobilis leaf-shaped with rounded apex. Maxillula (Fig. $5 \mathrm{H}$ ) outer branch with $5+5$ teeth, apically entire, and two thick plumose stalks; inner branch with three penicils, proximal one longer than two apical. Maxilla (Fig. 5I) with setose and bilobate apex, outer lobe smaller. Maxilliped (Fig. 5J) basis enlarged on distal portion bearing fringe of fine setae; first article of palp with two setae, distal articles fused bearing distal tufts of several thin setae; endite rectangular, outer and medial margins setose, apically with two triangular teeth and large rounded penicil. Uropod (Fig. 6A) branches inserted at same level, endopod slightly longer than exopod. Pereopods 1-7 gradually elongated, pereopods 1-7 merus, carpus, and propodus bearing sparse setae and fringed scales (discernible over $200 \times$ magnification) on sternal margin, pereopod 7 basis with scales of water conduction system; dactylus of one claw bearing many setae on inner and outer margins.

Male. Pereopods 1-6 (Fig. 6B-G) merus with proximal portion bearing fringed scales and thin setae on sternal margin. Pereopod 1 (Fig. 6B) carpus with large antennal grooming brush. Pereopod 5 (Fig. 6F) slightly depressed on distal sternal margin. Pereopod 6 (Fig. 6G) ischium flattened on sternal portion bearing brush of fine setae. Pereopod 7 (Fig. 6H) ischium with straight sternal margin, merus and carpus with no distinct modifications. Genital papilla (Fig. 7A) lanceolate, enlarged on median portion, apical part narrow. Pleopod 1 (Fig. 7B) exopod subtriangular bearing two short setae; endopod longer than exopod, narrow basal article and flagelliform distal article; basipod with triangular medial part fringed with fine and long setae on outer and 


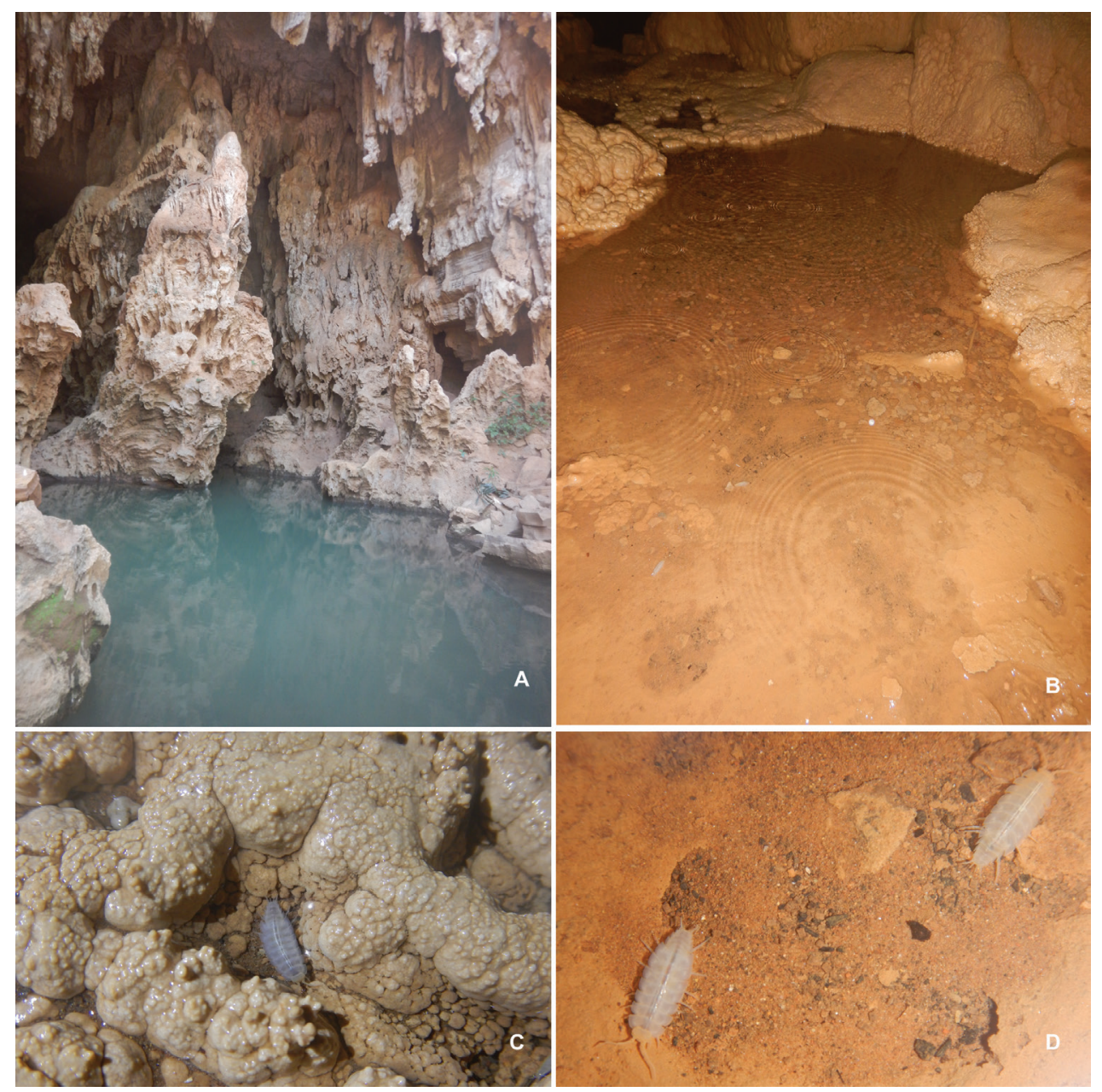

Figure 2. Natural habitat and habitus of Xangoniscus lapaensis sp. nov. A entrance of Gruna Boca da Lapa cave B travertine pools where Xangoniscus lapaensis sp. nov. occurs $\mathbf{C}$ specimen of Xangoniscus lapaensis sp. nov. submerged on rocky substrate at the travertine pools D specimens of Xangoniscus lapaensis sp. nov. submerged on silt and rocky substrate.

distal margins, distal margin strongly sinuous. Pleopod 2 (Fig. 7C) exopod triangular, median portion narrower, distal margin almost straight bearing three setae; endopod of two thickset articles, second article about three times as long as first, with complex apical part: distal margin subquadrangular with narrow transverse process, subapical triangular lobe strongly folded. Pleopod 3 exopod (Fig. 7D) subtriangular, longer than wide, covering pleopods 1 and 2, bearing many short setae, distal external margin straight. Pleopod 4 and 5 exopods (Fig. 7E, F) subrectangular, wider than long, with distal portion bearing many short setae.

Etymology. The new species is named after the locality where the specimens were collected, Gruna Boca da Lapa, an important cave discovered and mapped by Grupo 
Bambuí de Pesquisas Espeleológicas (GBPE) in 1991 and only now is it studied in relation to its cave fauna.

Remarks. Xangoniscus lapaensis sp. nov. resembles $X$. aganju in the shape of the male pleopod 2 endopod; however, it differs in the vertex of the cephalon that lacks a frontal groove, and with a more pronounced suprantennal line that surpasses the antennule insertion (not surpassing in $X$. aganju). Also, the male pereopod 6 carpus lacks any modification (strongly modified in $X$. aganju, see Campos-Filho et al. 2014); the male pleopod 1 exopod is not elongated, and the male pleopod 2 exopod is narrower on inner portion. Moreover, X. lapaensis sp. nov. differs in the uropod endopod slightly longer than exopod (opposite in $X$. aganju) and the compact triangular shape of the male pleopod 1 exopod (elongated in $X$. aganju).

Ecology and behavior. Xangoniscus lapaensis sp. nov. occurs in travertine pools fed by infiltration of water through the limestone rock, dripping from the cave ceiling, and in isolated pools along the cave (Fig. 2B, C), distributed from the twilight until the aphotic zone, something that demonstrates that its distribution is related to pools formed by infiltration water, i.e., its special habitat is available. The microhabitat is composed of rocky substrate, with little silt and sand sediment. The water is clear, with a very slow current, and a depth varying from $0.05 \mathrm{~m}$ to $0.15 \mathrm{~m}$ (Fig. 2B-D). Physicochemical variables were typical of karst aquifers that have high $\mathrm{pH}$ values: $\mathrm{pH}$ $=8.5-9.0, \mathrm{~T}=23.5^{\circ} \mathrm{C}$, very different from the conditions in the base-level river $(\mathrm{pH}=$ $7.5, \mathrm{~T}=25^{\circ} \mathrm{C}$ ). A small quantity of organic and particulate matter was observed in the small pools. Population density in the pools was high, ranging 6.5 to 32 individuals. $\mathrm{m}^{-2}$ and the abundance was 74 individuals in an area of $2.8 \mathrm{~m}^{2}$. The locomotor behavior was very particular, exhibiting fast and effective walking movements when submerged. However, when emerging from water, individuals showed a slow walking behavior on terrestrial substrate (see Supplementary Online Material 1). Xangoniscus lapaensis sp. nov. did not show photophobic behavior (indifferent to flashlight of about 600 lumens), and also seemed to exhibit intraspecific interactions, with no agonistic behavior. Adults and juveniles were observed in the pools, representing possible recruitment at the end of the dry season. It appears that $X$. lapaensis sp. nov. occurs preferentially in microhabitats fed by infiltration water, since no individual was recorded in the stream of the cave, a base-level river. This is very specific and unique, and probably the main habitat of this species is the spaces in the rocks filled by water.

\section{Xangoniscus loboi Campos-Filho, Galláo \& Bichuette, sp. nov.} http://zoobank.org/0572EC0F-C9B4-4B05-804C-3606AC59A8AF Figures 1, 3, 8-11

Type locality. Bahia, Feira da Mata, Gruna da Pingueira II cave $\left(14^{\circ} 12^{\prime} 04.3^{\prime \prime S}\right.$, 442 $4^{\prime} 39.1^{\prime \prime W) . ~}$

Type material. Holotype male (LES 27737), Bahia, Feira da Mata, Gruna da Pingueira II cave, 14 October 2020, leg. ME Bichuette, DF Torres, JS Gallo \& JE Gallão. Para- 

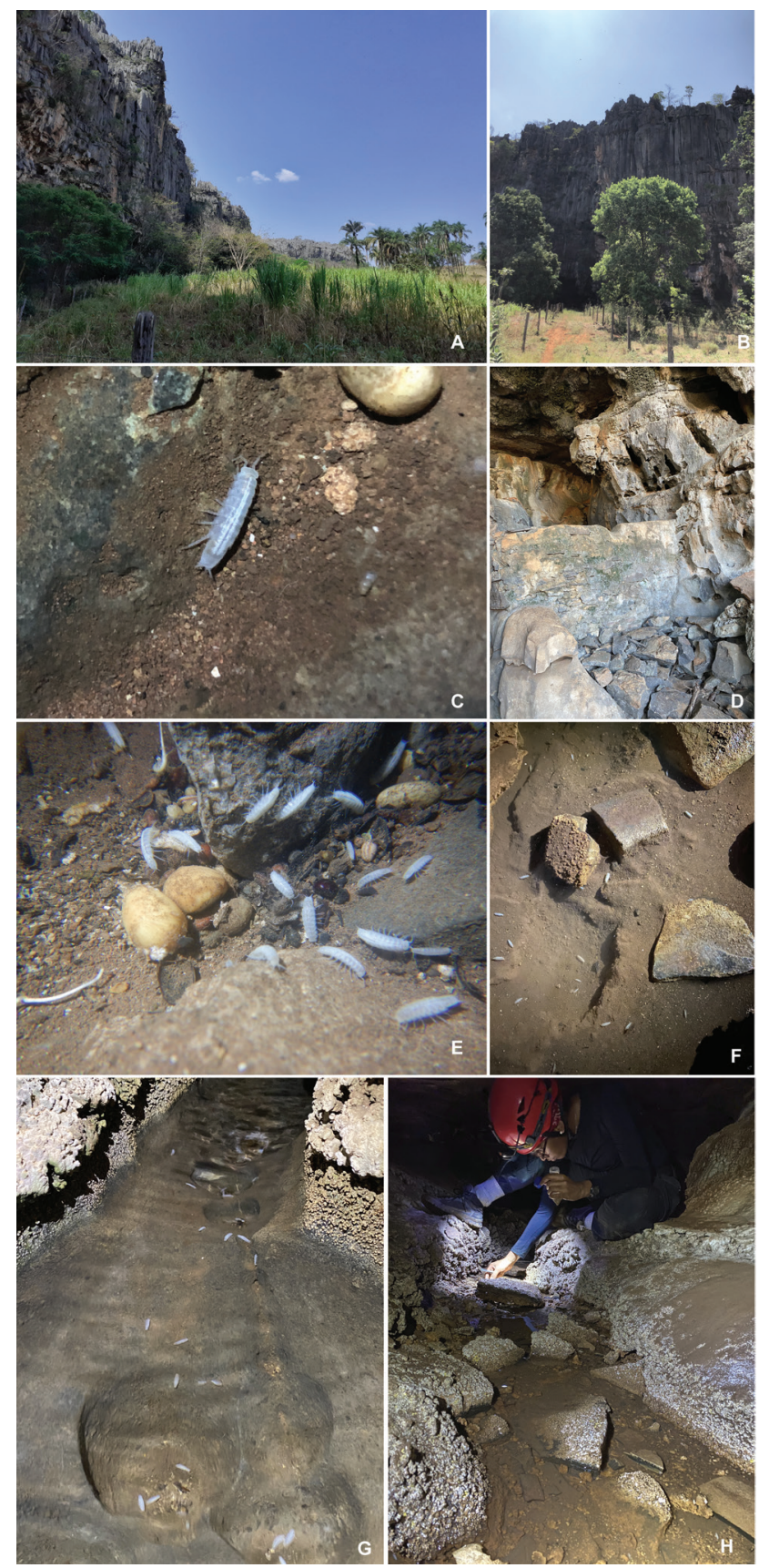

Figure 3. Natural habitat and habitus of Xangoniscus loboi sp. nov. A karst area where Gruna da Pingueira II cave is located B karst and entrance of Gruna da Pingueira II cave $\mathbf{C}$ specimen of Xangoniscus loboi sp. nov. submerged on the silt substrate $\mathbf{D}$ damn inside the cave $\mathbf{E}$ specimens of Xangoniscus loboi sp. nov. feeding on seed fruits $\mathbf{F}$ specimens of Xangoniscus loboi sp. nov. submerged on silt and rocky substrate G specimens of Xangoniscus loboi sp. nov. submerged on the rocky substrate $\mathbf{H}$ stream inside Gruna da Pingueira II cave where Xangoniscus loboi sp. nov. occurs. 


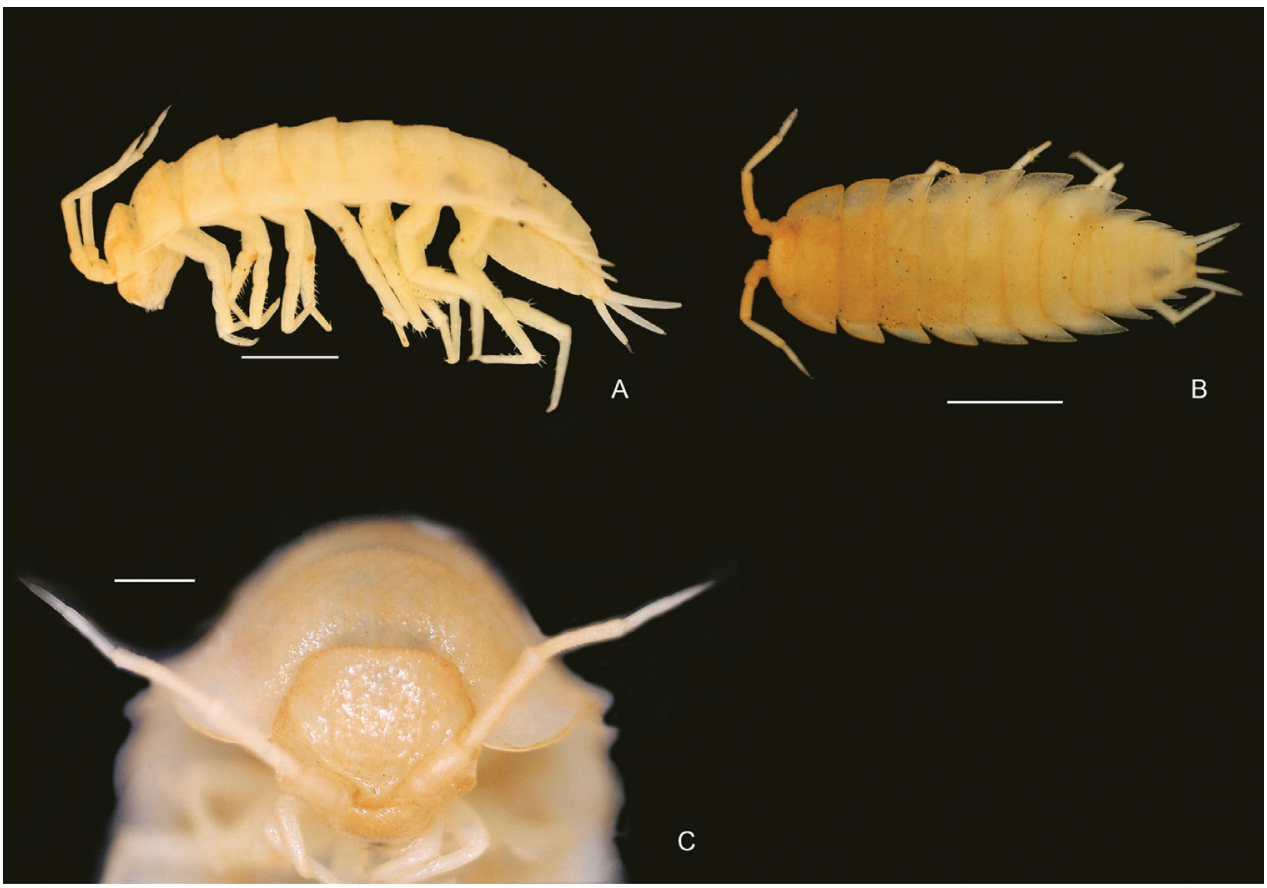

Figure 4. Xangoniscus lapaensis sp. nov. A habitus, lateral view $\mathbf{B}$ habitus, dorsal view $\mathbf{C}$ cephalon and pereonites 1-4, dorsal view. Scale bar: $2 \mathrm{~mm}(\mathbf{A}, \mathbf{B}) ; 1 \mathrm{~mm}(\mathbf{C})$.

types 2 males, 3 females (one female with parts in micropreparations) (LES 27738), 6 males (one male in micropreparations), 4 females (LES 27739), same data as holotype.

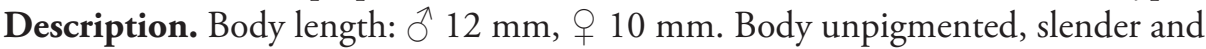
elongated, lateral sides almost parallel (Figs 3C, E, 8A-C). Dorsal surface smooth with scattered fringed scale setae (Figs 8C, 9A). Pereonite 1 epimera with distal corners not developed frontwards, posterior corners right-angled; pereonites 2-4 epimera gradually directed backwards, posterior corners progressively more acute; pleon slightly narrower than pereon, pleonites 3-5 epimera very short, slightly visible on dorsal view (Figs 8A, 9C). Cephalon (Figs 8D, 9B) with large quadrangular antennary lobes; vertex with slightly lateral depression to fit antennae when extended backwards, profrons with $\mathrm{V}$-shaped suprantennal line, not surpassing antennule insertion; eyes absent. Telson (Fig. 9C) with well pronounced concave sides and broadly rounded apex. Antennula (Fig. 9D) of three articles, proximal and distal articles subequal in length, second article bearing short setae on inner margin, distal article with five aesthetascs. Antenna (Fig. 9E) with fifth article of peduncle longer than flagellum; flagellum of four articles, first article longest, distal article bearing tuft of free sensilla. Left mandible (Fig. 9F) with two penicils, right mandible (Fig. 9G) with one penicil and lacinia mobilis leaf shaped. Maxillula (Fig. 9H) outer branch with $5+5$ teeth, apically entire, and two thick plumose stalks; inner branch with three penicils, proximal one longer than two apical. Maxilla (Fig. 9I) with setose and bilobate apex, outer lobe smaller bearing one strong 


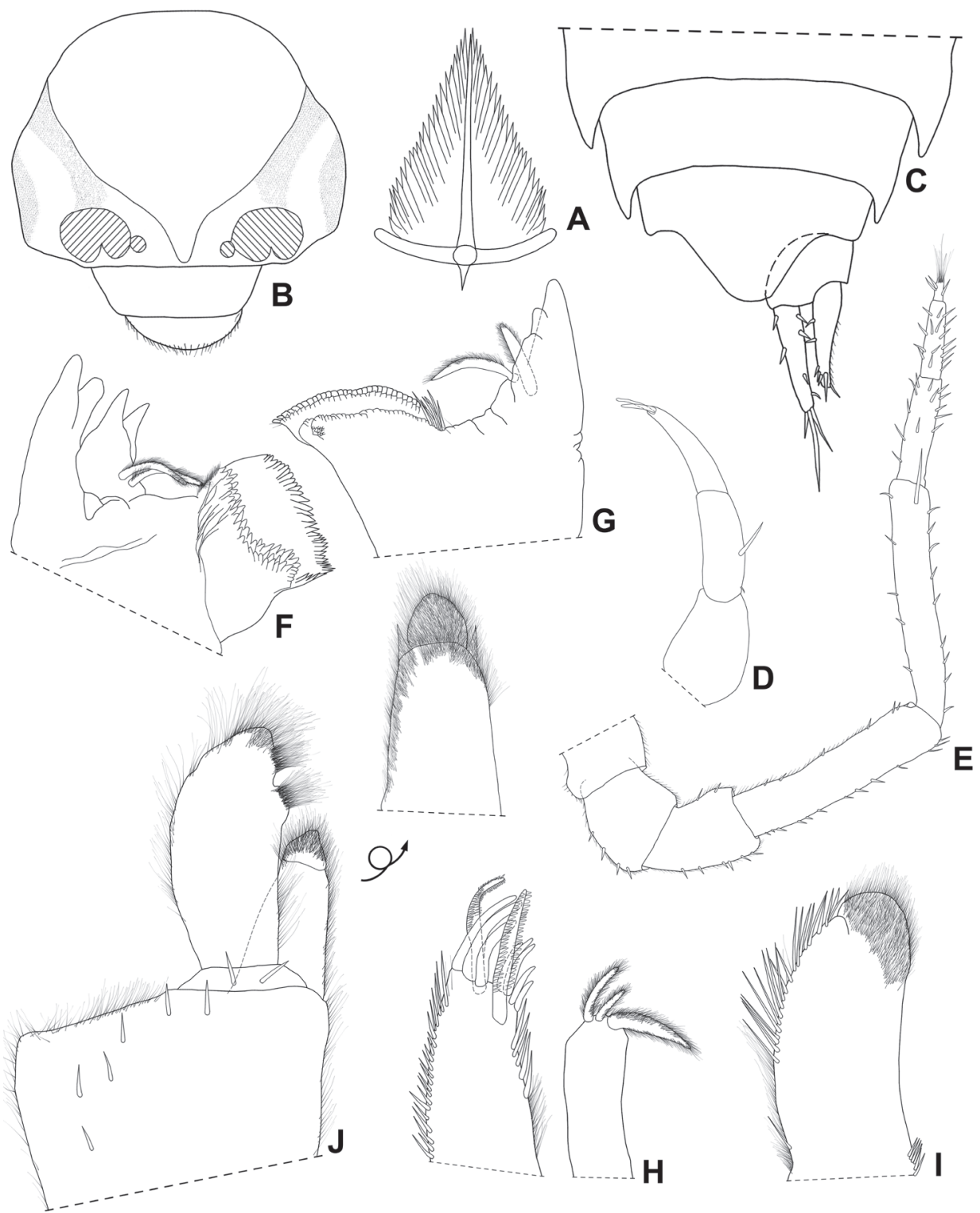

Figure 5. Xangoniscus lapaensis sp. nov. Male $\mathbf{A}$ dorsal scale-setae $\mathbf{C}$ pleonites 4 and 5, telson and uropod. Female $\mathbf{B}$ cephalon, frontal view $\mathbf{D}$ antennula $\mathbf{E}$ antenna $\mathbf{F}$ left mandible $\mathbf{G}$ right mandible $\mathbf{H}$ maxillula I maxilla J maxilliped.

seta. Maxilliped (Fig. 9J) basis enlarged on distal portion bearing fringe of fine setae; first article of palp with two setae, distal articles fused bearing distal tufts of fine setae; endite rectangular, outer and medial margins setose, apically with one triangular teeth and large triangular penicil. Uropod (Fig. 10A) branches inserted at same level, endo- 


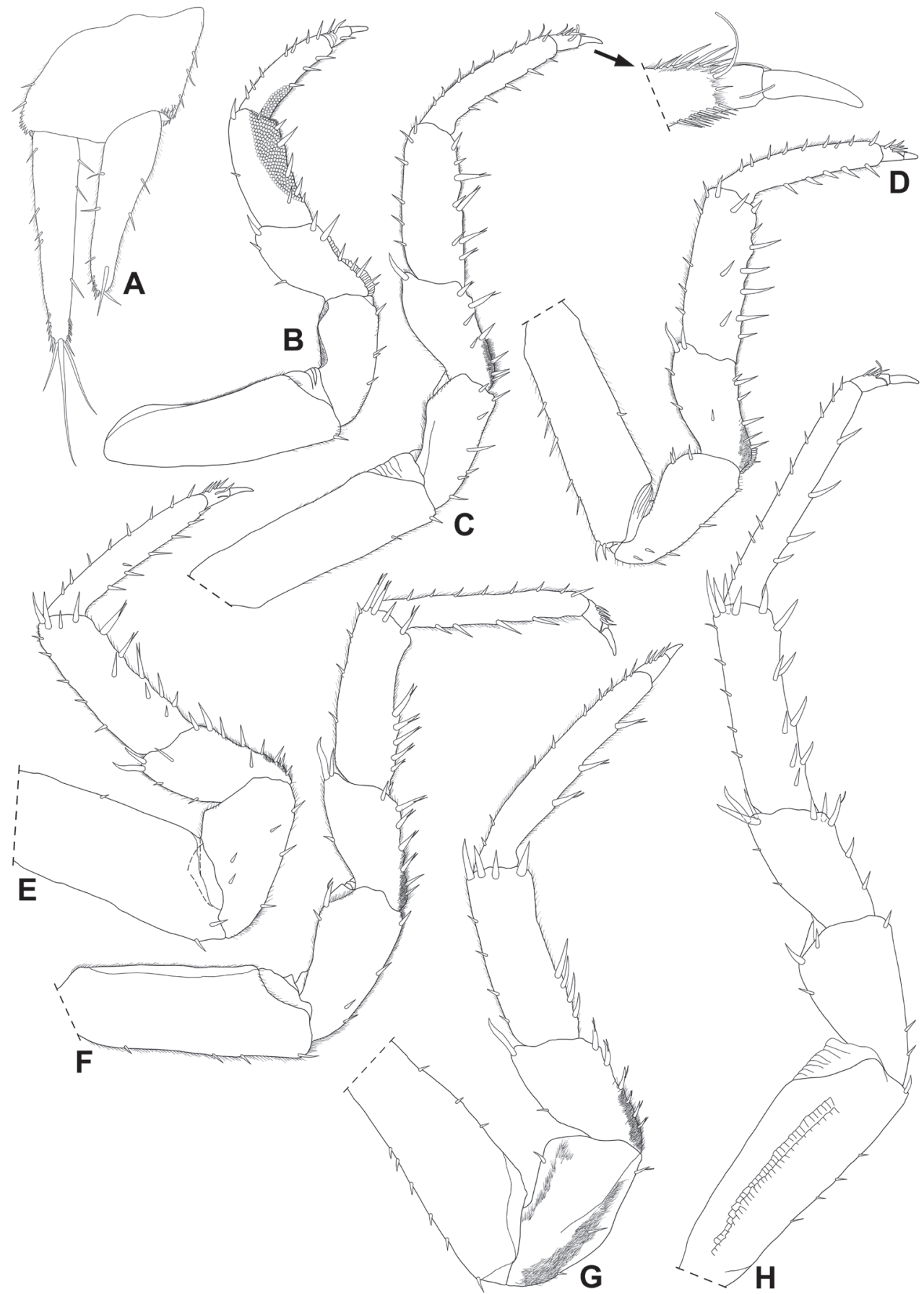

Figure 6. Xangoniscus lapaensis sp. nov. Male A uropod B pereopod 1 C pereopod 2 D pereopod 3 E pereopod $4 \mathbf{F}$ pereopod $5 \mathbf{G}$ pereopod $6 \mathbf{H}$ pereopod 7. 


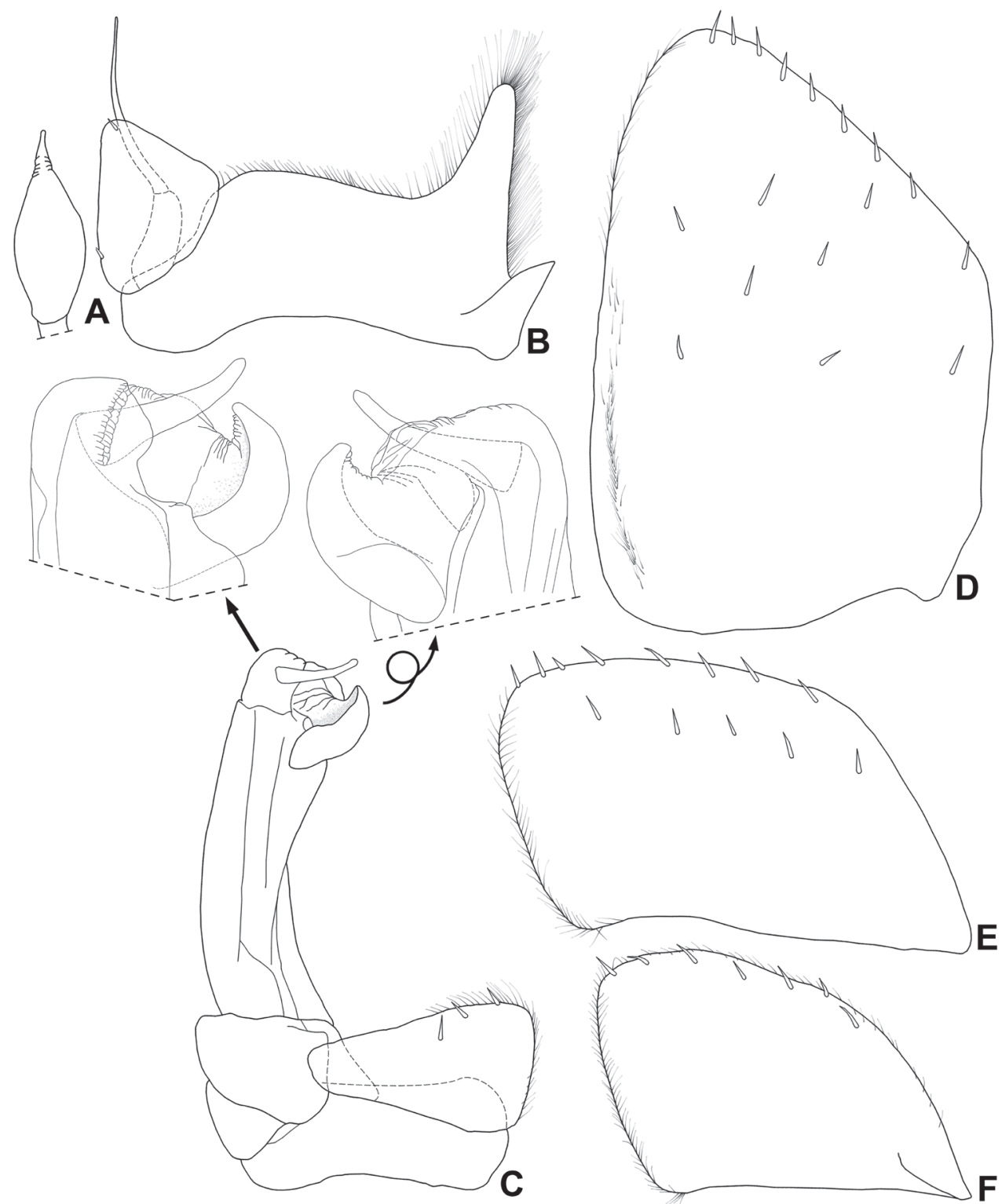

Figure 7. Xangoniscus lapaensis sp. nov. Male A genital papilla B pleopod 1 C Pleopod 2 D pleopod 3 exopod $\mathbf{E}$ pleopod 4 exopod $\mathbf{F}$ pleopod 5 exopod.

pod and exopod subequal in length. Pereopods 1-7 gradually elongated, pereopods 1-7 merus, carpus and propodus bearing sparse setae and fringed scales (discernible over 200x magnification) on sternal margin, pereopod 7 basis with scales of water conduction system; dactylus of one claw bearing many setae on inner and outer margins.

Male. Pereopods 1-3 (Fig. 10B-D) merus with proximal lobe bearing fringed scales and fine setae on sternal margin. Pereopods 4-6 (Fig. 10E-G) merus with dense field of 


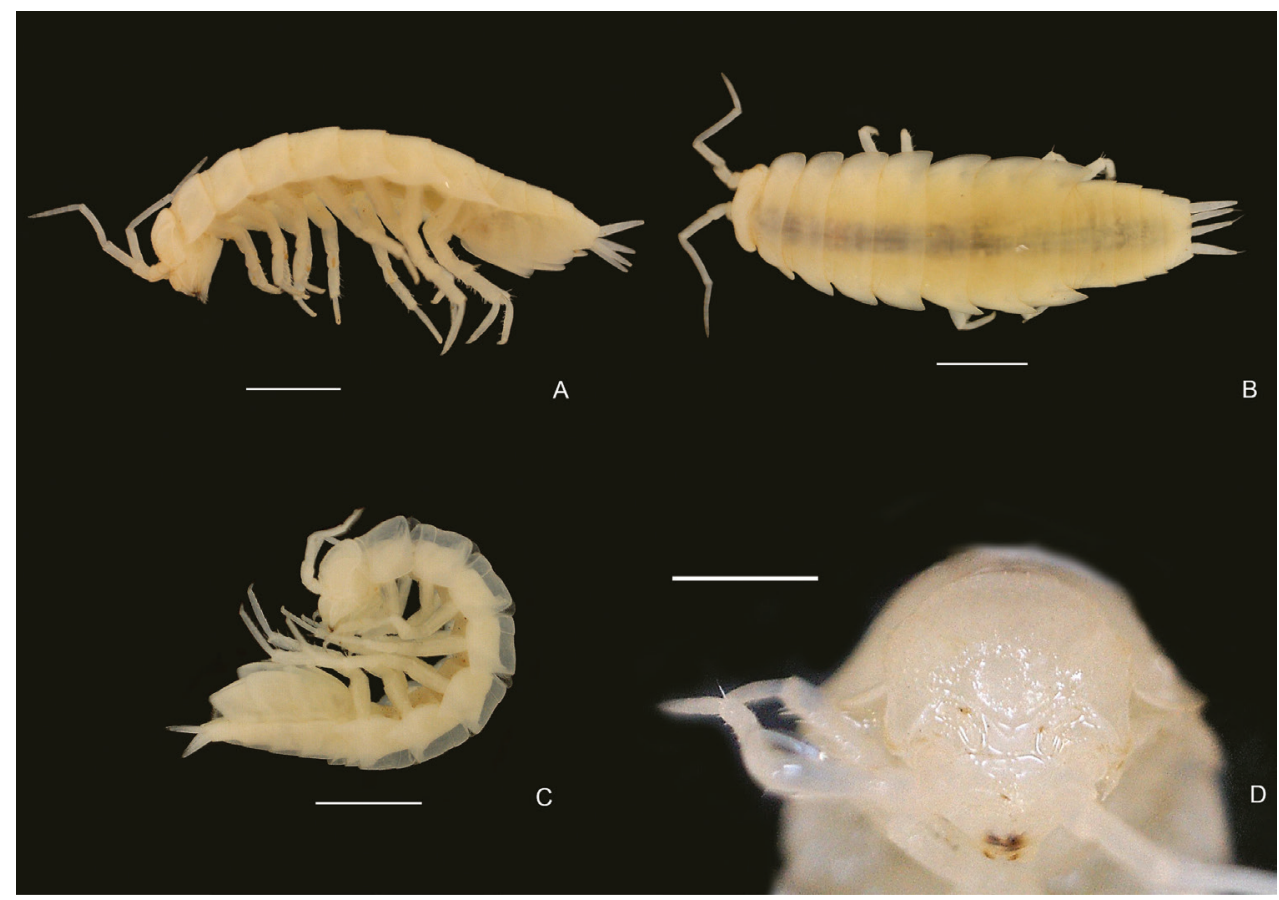

Figure 8. Xangoniscus loboi sp. nov. A habitus, lateral view B habitus, dorsal view $\mathbf{C}$ habitus, lateral view D cephalon and pereonite 1, frontal view. Scale bar: $2 \mathrm{~mm}(\mathbf{A}-\mathbf{C}) ; 1 \mathrm{~mm}(\mathbf{D})$.

short setae on sternal margin. Pereopod 6 (Fig. 10G) merus bearing brush of setae on sternal margin. Pereopod 7 (Fig. 10H) ischium straight on sternal margin, merus, and carpus with no distinct modifications. Genital papilla (Fig. 11A) lanceolate, enlarged on median portion, apical part narrow and pointed. Pleopod 1 (Fig. 11B) exopod subtriangular, longer than wide, inner and outer margins bearing fringe of fine setae; endopod slightly longer than exopod, narrow basal article and flagelliform distal article; basipod with stout and broadly rounded medial part bearing fringe of fine setae along outer and distal margins. Pleopod 2 (Fig. 11C) exopod triangular, median portion narrower, distal margin almost straight bearing three setae; endopod of two thickset articles, second article about three times as long as first, with complex apical part: distal margin rounded with two narrow transverse processes, subapical circular lobe strongly folded. Pleopod 3 exopod (Fig. 11D) triangular, slightly longer than wide, covering pleopods 1 and 2, bearing many short setae on distal margin. Pleopod 4 exopod (Fig. $11 \mathrm{E})$ subrectangular, wider than long, distal portion bearing many short setae. Pleopod 5 exopod (Fig. 11F) subtrapezoidal, distal margin rounded bearing many short setae.

Etymology. The new species is named after Alexandre Lobo for all his contributions for knowledge and conservation of the Brazilian speleological heritage.

Remarks. Xangoniscus loboi sp. nov. differs from all other species of the genus in having the proximal lobe of male pereopods $1-3$ merus covered with scales and fine setae, and in the shape of the distal complex apparatus of the male pleopod 2 endopod. 


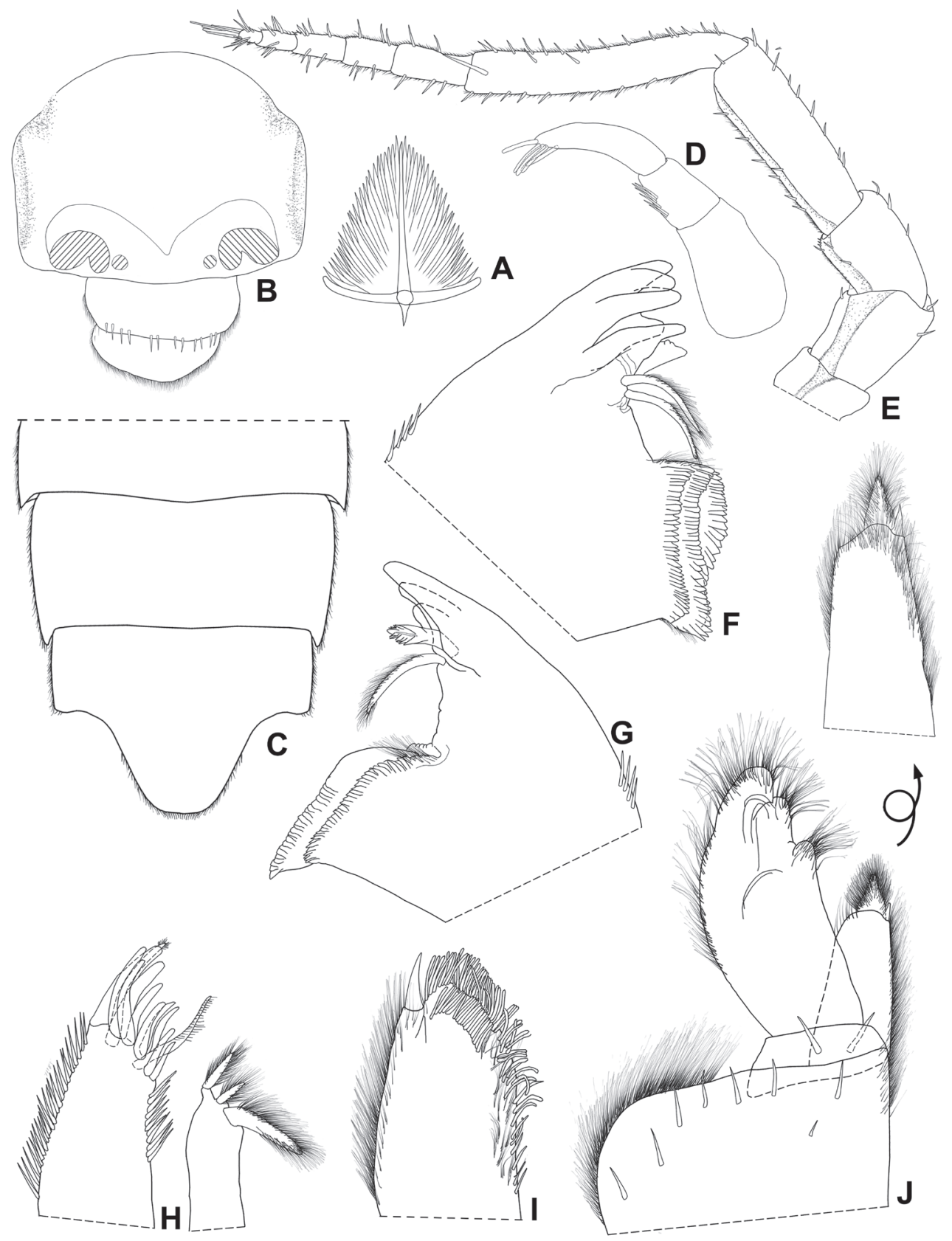

Figure 9. Xangoniscus loboi sp. nov. Male A dorsal scale-seta B cephalon, frontal view $\mathbf{C}$ pleonites 4, 5 and telson $\mathbf{D}$ antennula $\mathbf{E}$ antenna $\mathbf{F}$ left mandible $\mathbf{G}$ right mandible $\mathbf{H}$ maxillula $\mathbf{I}$ maxilla $\mathbf{J}$ maxilliped.

Ecology and behavior. Xangoniscus loboi sp. nov. occurs in a small stream formed by infiltration water in the limestone rock (Fig. 3). The small stream crosses an extension of about $9 \mathrm{~m}$ through the cave entrance and the twilight zones, with 


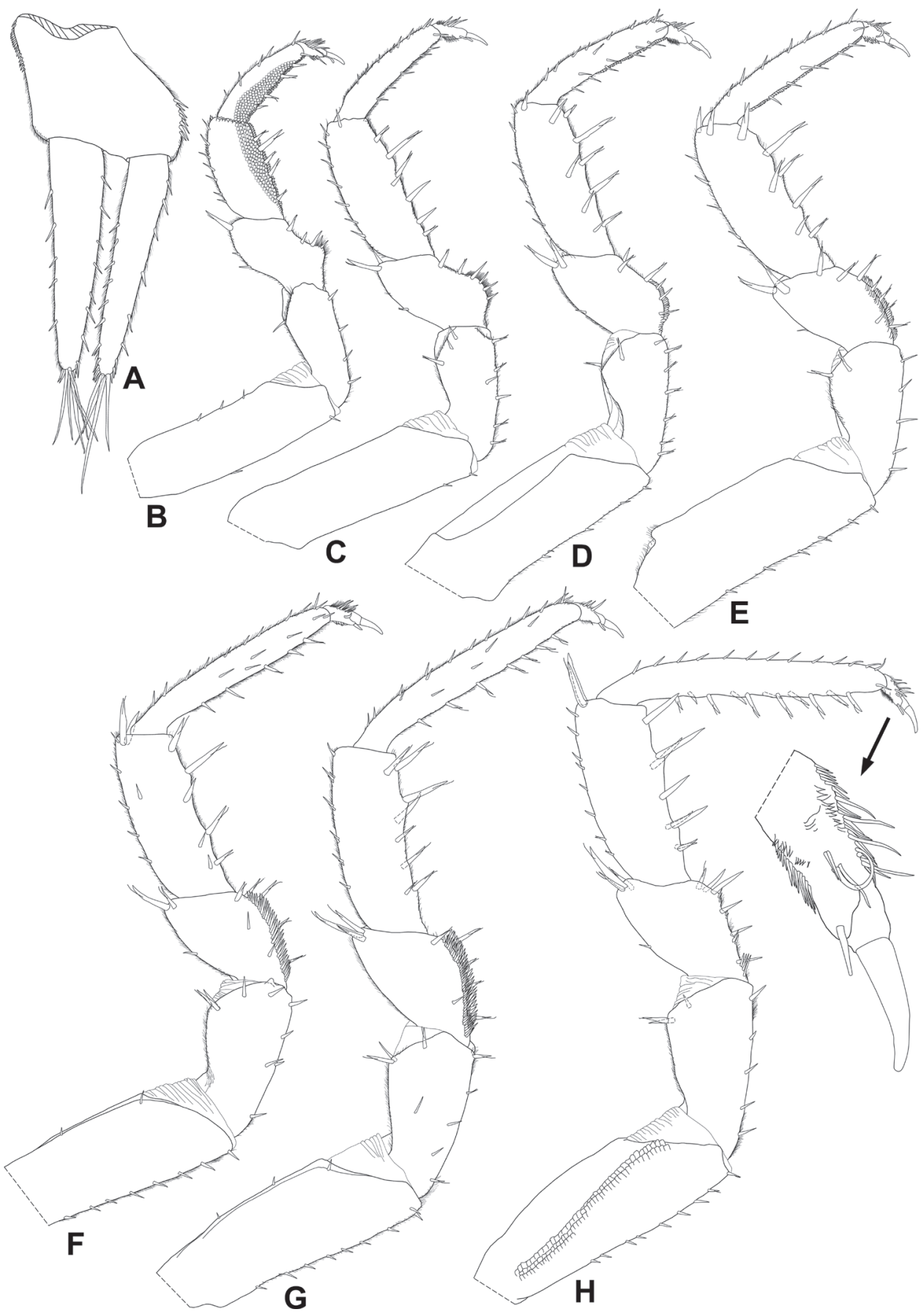

Figure I 0. Xangoniscus loboi sp. nov. Male $\mathbf{A}$ uropod B pereopod $1 \mathbf{C}$ pereopod $2 \mathbf{D}$ pereopod $3 \mathbf{E}$ pereopod $4 \mathbf{F}$ pereopod $5 \mathbf{G}$ pereopod $6 \mathbf{H}$ pereopod 7. 


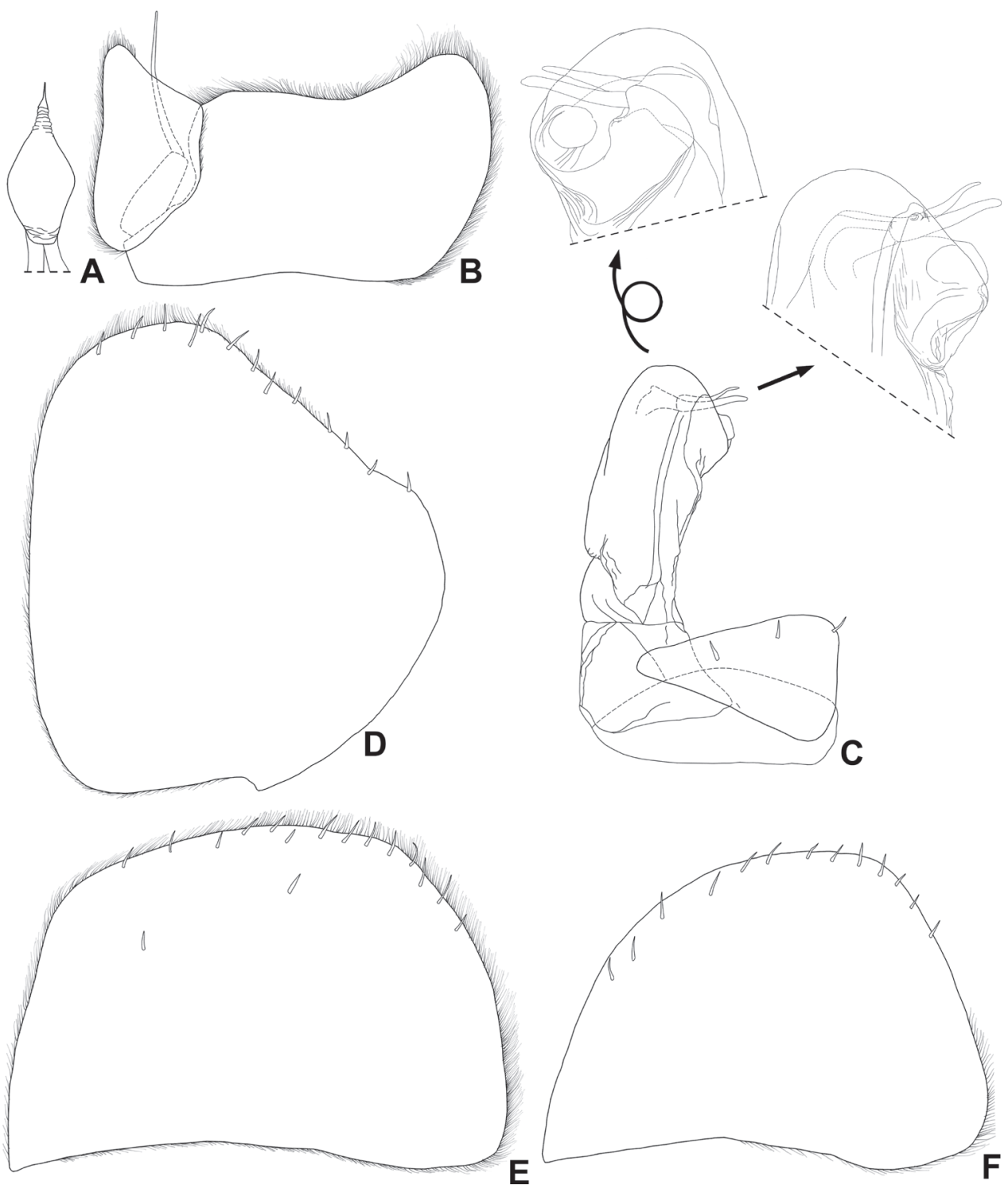

Figure II. Xangoniscus loboi sp. nov. Male A genital papilla B pleopod 1 C Pleopod 2 D pleopod 3 exopod E pleopod 4 exopod $\mathbf{F}$ Pleopod 5 exopod.

width varying from 0.2 to $1.2 \mathrm{~m}$ and depth from 0.05 to $0.25 \mathrm{~m}$. Along the stream, two small waterfalls (ca. $0.6 \mathrm{~m}$ of length) with a rocky substrate were observed. In these stretches, the individuals were seen constantly climbing the substrate (see Supplementary Online Material 2). The bottom of the stream is composed mainly of rocky substrate (concretions and small pebbles), with silt and sand sediment in the bottom, offering rich shelter for the isopods (Fig. $3 \mathrm{C}, \mathrm{E}-\mathrm{H}$ ). The water is clear, with a very slow current. Physicochemical variables are typical of karst aquifers (high 
$\mathrm{pH}$ values), $\mathrm{pH}=8.0-8.5, \mathrm{~T}=24.1^{\circ} \mathrm{C}$. A low load of organic and particulate matter was observed in the stream, with some seeds of fruits in the sector close to the cave entrance. The population density in three sectors of the stream were: 54 inds. $\mathrm{m}^{-2}, 67$ inds. $\mathrm{m}^{-2}$ and 342 inds. $\mathrm{m}^{-2}$; minimal abundance was 455 individuals in an area of ca. 5.0 $\mathrm{m}^{2}$. As observed for $X$. lapaensis sp. nov., the locomotor behavior was very particular. Xangoniscus loboi sp. nov. shows an efficient walking behavior when submerged (see Supplementary Online Material 3) and climbs vertical stretches (upstream direction) in the stretches with relatively strong water flow. They are clumsy out of water (they do not perform as well as in the submersion behavior), but they adhere very well on dry rock. We also observed copulation: three different couples in reproductive behavior, mated for several minutes (at least $5 \mathrm{~min}$.) (see Supplementary Online Material 4 and 5). Several adults and juvenile individuals were observed along the stream, representing possible recruitment at the end of the dry season. Other interesting behaviors are the indifference to light, even under strong flashlight (ca. 600 lumens), and the interactions among several individuals, touching each other, showing no signs of agonistic behavior. In relation to feeding behavior, some individuals were observed foraging on vegetal debris and seeds (see Supplementary Online Material 6). It appears that X. loboi sp. nov. occurs preferentially in microhabitats fed by infiltration water in the limestone. This is very specific and unique, and probably the main habitat of this species is the spaces in rocks filled by water.

\section{Discussion}

Both species described herein show the classical signs of troglomorphism (eyes absent and body depigmented), as observed for the other eight valid species of Xangoniscus, i.e., $X$. aganju, $X$. ceci, $X$. dagua, $X$. ibiracatuensis, $X$. itacarambiensis, $X$. lundi, X. odara and $X$. santinhoi. This could be a pattern for the entire genus, since all species described until now show these same characteristics. Morphological variability in these two characters was not observed for any species of Xangoniscus. To date, no Xangoniscus species has been recorded outside caves, in the epigean environment, which may denote an ancient isolation of this group.

Morphologically, $X$. lapaensis sp. nov. and $X$. aganju (including specimens from Gruna Chico Pernambuco and Domingão caves, see Campos-Filho et al. 2019) exhibit some level of similarities in the pereopods 5 and 6 of males, e.g., merus and carpus with fringed scales and dense field of thin setae on external margin and carpus distally depressed (see figures of $X$. aganju in Campos-Filho et al. 2014). The complex shape of the distal portion of the male pleopod 2 endopod is quite similar among specimens of $X$. aganju from Gruna do Mandiaçu cave (type locality) and Gruna Chico Pernambuco cave and X. lapaensis sp nov. (see figure 13C in Campos-Filho et al. 2014, and figure 7B in Campos-Filho et al. 2019), and specimens of $X$. aganju from Domingão cave and $X$. loboi sp. nov. shares the presence of two transverse processes (see figure $7 \mathrm{C}$ in Campos-Filho et al. 2019). Taking into account the geographic distribution of these 
species (see Fig. 1) and these morphological characteristics, it is likely that these species represent a species complex. Future phylogenetic analyses potentially will elucidate the hypotheses proposed herein.

The Serra do Ramalho region has been locally exploited historically by agriculture activities and charcoal production on a small scale. At a broader scale, mining projects and large agriculture production along the boundaries of the region pose future threats (Gallão \& Bichuette, 2018) (Fig. 1C, D). To date, no effective law guarantees protection of the caves in the region. However, both Gruna Boca da Lapa and Gruna da Pingueira II caves are type-localities of endemic and probably rare troglobites, classifying these caves as maximum relevance sensu Brazilian legislation (BRASIL 2008). However, this action likely will not be sufficient, because protection is restricted to a small portion of an extensive massif. The creation of a conservation unit for the entire karst area would probably be the most effective action to ensure the preservation of the biological and speleological heritage of the Serra do Ramalho karst region.

A preliminary evaluation of the conservation status of these species was conducted following the IUCN (International Union of Conservation of Nature) classification. Despite their high population density and abundance, Xangoniscus lapaensis sp. nov. and Xangoniscus loboi sp. nov. were classified as Critically Endangered (CR) according to the criteria B2ab(iii). Both species are endemic, restricted to their type-locality and found in a specific microhabitat (travertine pools and streams formed by infiltration water). The surrounding areas of the cavities are impacted by deforestation for pastures and the native vegetation is present only at their entrances (Fig. 3A, B). Furthermore, the Gruna Boca da Lapa cave is threatened by uncontrolled tourism. These threats, combined with the impacts mentioned above for the Serra do Ramalho region, justify the conservation status proposed in this evaluation.

\section{Acknowledgements}

We thank ICMBio/CECAV (Instituto Chico Mendes para Conservação da Biodiversidade/Centro Nacional de Pesquisa e Conservação de Cavernas) for financial support to the project "Estudos para definição de áreas prioritárias para a Conservação de Proteção Espeleológico na Serra do Ramalho - BA", under execution by the GBPE (Grupo Bambuí de Pesquisas Espeleológicas), coordinated by Ezio Rubbioli and integrated by MEB and LH; to the members of GBPE, E Rubbioli, F Chaimowicz, A Lobo and R Brandi for all support in the occasion of the discovery of the new species; a special thanks to GBPE for sharing speleological information of Serra do Ramalho karst area with MEB and for all contribution to the knowledge of Brazilian caves; to SISBIO (Sistema de Autorizaçáo Informação em Biodiversidade) for collection permit to MEB (28992); to Vicerrectoría de Investigaciones of the University of Cartagena for the financial support to the Grupo de Investigación en Biología Descriptiva y Aplicada (Project Redes de Investigación Científica, Acta de Compromiso N 017-2020); to CAPES (Coordenação de Aperfeiçoamento 
de Pessoal de Nível Superior) for financial support to ISC-F during his postdoctoral fellowship (CAPES/PNPD/UFCG/CTRN/PPGRN/201713705) (Finance Code 001); to $\mathrm{CNPq}$ (Conselho Nacional de Desenvolvimento Científico e Tecnológico) for productivity fellowship to MEB (310378/2017-6). We would like to thank the anonymous reviewers and editor Dr. ML Niemiller for their critiques and suggestions for the work.

\section{References}

Altmann J (1974) Observational study of behavior: Sampling methods. Behaviour 49(3-4): 227-267. https://doi.org/10.1163/156853974X00534

Anderson LE (1954) Hoyer's Solution as a Rapid Permanent Mounting Medium for Bryophytes. The Bryologist 57: e242. https://doi.org/10.2307/3240091

Auler AS, Rubbioli EL, Brandi R (2001) As grandes cavernas do Brasil. Belo Horizonte: Grupo Bambuí de Pesquisas Espeleológicas.

Bastos-Pereira R, Souza LA, Ferreira RL (2017) A new amphibious troglobitic styloniscid from Brazil (Isopoda, Oniscidea, Synocheta). Zootaxa 4294(2): 292-300. https://doi. org/10.11646/zootaxa.4294.2.11

Bedek HE, Zimmermann NE, McVicar TR, Vergopolan N, Berg A, Wood EF (2018) Present and future Köppen-Geiger climate classification maps at 1-km resolution. Scientific Data 5: e180214. https://doi.org/10.1038/sdata.2018.214

Bedek HE, Zimmermann NE, McVicar TR, Vergopolan N, Berg A, Wood EF (2020) Publisher Correction: Present and future Köppen-Geiger climate classification maps at 1-km resolution. Scientific Data 7: e274. https://doi.org/10.1038/s41597-020-00616-w

Belda M, Holtanová E, Halenka T, Kalvová J (2014) Climate classification revisited: from Köppen to Trewartha. Climate Research 59: 1-13. https://doi.org/10.3354/cr01204

BRASIL (2008) Decreto $n^{\circ} 6.640$, de 7 de novembro de 2008. Dá nova redação aos arts. $1^{\circ}, 2^{\circ}$, $3^{\circ}, 4^{\circ}$ e $5^{\circ}$ e acrescenta os arts. 5-A e 5-B ao Decreto no 99.556, de $1^{\circ}$ de outubro de 1990 , que dispôe sobre a proteção das cavidades naturais subterrâneas existentes no território nacional. Diário Oficial [da República Federativa do Brasil], Brasília. http://www.planalto.gov. br/ccivil_03/_Ato2007-2010/2008/Decreto/D6640.htm [accessed 29 September 2021].

Campos-Filho IS, Araujo PB, Bichuette ME, Trajano E, Taiti S (2014) Terrestrial isopods (Crustacea: Isopoda: Oniscidea) from Brazilian caves. Zoological Journal of the Linnean Society 172(2): 360-425. https://doi.org/10.1111/zoj.12172

Campos-Filho IS, Bichuette ME, Araujo PB, Taiti S (2017b) Description of a new species of Cylindroniscus Arcangeli, 1929 (Isopoda: Oniscidea) from Brazil, with considerations on the family placement of the genus. North-Western Journal of Zoology 13(2): e161305. https://biozoojournals.ro/nwjz/content/v13n2/nwjz_e161305_Campos.pdf [accessed 21 September 2021].

Campos-Filho IS, Bichuette ME, Montesanto G, Araujo PB, Taiti S (2017a) The first troglobiotic species of the family Pudeoniscidae (Crustacea, Isopoda, Oniscidea), with descriptions of a new genus and two new species. Subterranean Biology 23: 69-84. https://doi. org/10.3897/subtbiol.23.20963 
Campos-Filho IS, Bichuette ME, Taiti S (2016) Three new species of terrestrial isopods (Crustacea, Isopoda, Oniscidea) from Brazilian caves. Nauplius 24: 1-19. https://doi. org/10.1590/2358-2936e2016001

Campos-Filho IS, Cardoso GM, Aguiar JO (2018) Catalogue of terrestrial isopods (Crustacea, Isopoda, Oniscidea) from Brazil: an update with some considerations. Nauplius 26: e2018038. https://doi.org/10.1590/2358-2936e2018038

Campos-Filho IS, Fernandes CS, Cardoso GM, Bichuette ME, Aguiar JO, Taiti S (2019) Two new species and new records of terrestrial isopods (Crustacea, Isopoda, Oniscidea) from Brazilian caves. Zootaxa 4564(2): 422-448. https://doi.org/10.11646/zootaxa.4564.2.6

Campos-Filho IS, Fernandes CS, Cardoso GM, Bichuette ME, Aguiar JO, Taiti S (2020) New species and new records of terrestrial isopods (Crustacea, Isopoda, Oniscidea) of the families Philosciidae and Scleropactidae from Brazilian caves. European Journal of Taxonomy 606: 1-38. https://doi.org/10.5852/ejt.2020.606

Campos-Filho IS, Mise KM, Sessegolo GC (2015b) A new species of Trichorhina Budde-Lund, 1908 (Isopoda: Oniscidea: Platyarthridae) from Paraná caves, southern Brazil. Nauplius 23: 112-119. https://doi.org/10.1590/S0104-64972015002324

Campos-Filho IS, Taiti S (2021) Oniscidea taxonomy: present and future. Abstract book of the 11 th International Symposium on Terrestrial Isopod Biology, "Facets of terrestrial isopod biology". Ghent, Spinicornis, 9pp. https://spinicornis.be/istib2021/presentations/

Campos-Filho IS, Taiti S, Araujo PB (2015a) Taxonomic revision of the genus Benthana BuddeLund, 1908 (Isopoda: Oniscidea: Philosciidae). Zootaxa 4022(1): 1-73. https://doi. org/10.11646/zootaxa.4022.1.1

Cardoso GM, Bastos-Pereira R, Souza LA, Ferreira RL (2020a) New troglobitic species of Xangoniscus (Isopoda: Styloniscidae) from Brazil, with notes on their habitats and threats. Zootaxa 4819(1): 084-108. https://doi.org/10.11646/zootaxa.4819.1.4

Cardoso GM, Bastos-Pereira R, Souza LA, Ferreira RL (2020b) New cave species of Pectenoniscus Andersson, 1960 (Isopoda: Oniscidea: Styloniscidae) and an identification key for the genus. Nauplius 28: e2020039. https://doi.org/10.1590/2358-2936e2020039

Cardoso GM, Bastos-Pereira R, Souza LA, Ferreira RL (2021) Chaimowiczia: a new Iuiuniscinae genus from Brazil (Oniscidea, Synocheta, Styloniscidae) with the description of two new troglobitic species. Subterranean Biology 39: 45-62. https://doi.org/10.3897/subtbiol.39.65305

Dimitriou AC, Taiti S, Sfenthourakis S (2019) Genetic evidence against monophyly of Oniscidea implies a need to revise scenarios for the origin of terrestrial isopods. Nature Scientific Reports 9: e18508. https://doi.org/10.1038/s41598-019-55071-4

Fernandes CS, Batalha MA, Bichuette ME (2016) Does the cave environment reduce functional diversity? PLoS ONE 11(3): e0151958. https://doi.org/10.1371/journal.pone.0151958

Fernandes CS, Campos-Filho IS, Araujo PB, Bichuette ME (2019) Synopsis of terrestrial isopods (Crustacea: Isopoda: Oniscidea) from Brazilian caves, with emphasis on new records from north, midwest, northeast and southeast regions. Journal of Natural History 53(17-18): 1095-1129. https://doi.org/10.1080/00222933.2019.1634225

Fernandes CS, Campos-Filho IS, Bichuette ME (2018) Cylindroniscus platoi (Isopoda: Oniscidea: Styloniscidae), a new cave-dwelling species from Lagoa Santa Karst, Southeasthern Brazil. Zootaxa 4461 (3): 411-420. https://doi.org/10.11646/zootaxa.4464.3.6 
Galláo JE, Bichuette ME (2018) Brazilian obligatory subterranean fauna and threats to the hypogean environment. Zookeys 746: 1-23. https://doi.org/10.3897/zookeys.746.15140

Hornung E (2011) Evolutionary adaptation of oniscidean isopods to terrestrial life: structure, physiology and behavior. Terrestrial Arthropod Reviews 4: 95-130. https://doi. org/10.1163/187498311X576262

Javidkar M, Cooper SJB, King RA, Humphreys WF, Austin A (2015) Molecular phylogenetic analyses reveal a new southern hemisphere oniscidean family (Crustacea: Isopoda) with a unique water transport system. Invertebrate Systematics 29: 554-577. https://doi. org/10.1071/IS15010

Javidkar M, King RA, Cooper SJB, Humphreys WF, Austin A (2017) Taxonomy of Paraplatyarthrus Javidkar and King (Isopoda: Oniscidea: Paraplatyarthridae) with description of five new species from Western Australia, and comments on Australian Trichorhina Budde-Lunde, 1908 (Platyarthridae). Zootaxa 4243(3): 401-431. https://doi.org/10.11646/zootaxa.4243.3.1

Martin P, Bateson P (2007) Measuring Behaviour: An Introductory Guide. New York: Cambridge University Press, 246 pp. https://doi.org/10.1017/CBO9780511810893

Montesanto G (2015) A fast GNU method to draw accurate scientific illustrations for taxonomy. ZooKeys 515: 191-206. https://doi.org/10.3897/zookeys.515.9459

Montesanto G (2016) Drawing setae: a GNU way for digital scientific illustrations. Nauplius 24: e2016017. https://doi.org/10.1590/2358-2936e2016017

Richardson A, Araujo PB (2015) Lifestyles of terrestrial crustaceans. In: Thiel M, Watling L (Eds) The Natural History of the Crustacea. Lifestyles and Feeding Biology. Oxford, UK: Oxford University Press, 299-336.

Rubbioli E, Auler A, Menin D, Brandi R (2019) Cavernas-Atlas do Brasil Subterrâneo. Brasília, DF: ICMBio.

Schmalfuss H (2003) World catalog of terrestrial isopods (Isopoda: Oniscidea). Stuttgarter Beiträge zur Naturkunde, Serie A 654: 1-341.

Sfenthourakis S, Taiti S (2015) Patterns of taxonomic diversity among terrestrial isopods. ZooKeys 515: 13-25. https://doi.org/10.3897/zookeys.515.9332

Souza LA, Araújo JP, Campos-Filho IS (2011) The genus Trichorhina Budde-Lund in Brazil, with description of seven new species (Isopoda, Oniscidea, Platyarthridae). Iheringia Zoologia 101: 239-261. http://doi:10.1590/S0073-47212011000200012

Souza LA, Ferreira RL, Senna AR (2015) Amphibious shelter-builder Oniscidea species from the New World with description of a new subfamily, a new genus and a new species from Brazilian Cave (Isopoda, Synocheta, Styloniscidae). PLoS ONE 10(5): 1-18. https://doi. org/10.1371/journal.pone.0115021

Taiti S (2004) Crustacea: Isopoda: Oniscidea (woodlice). In: Gunn J (Ed.) Encyclopedia of caves and karst science. New York: Taylor and Francis Group, 547-551.

Taiti S (2018) Biologia e biogeografia degli isopodi terrestri (Crustacea, Isopoda, Oniscidea). Atti dell'Accademia nazionale italiana di Entomologia 65: 83-90.

Vandel A (1952) Les trichoniscides (crustaces - isopodes) de l'hemisphere austral. Memoires du Museum National d'Histoire Naturelle, Serie A 6: 1-116.

WoRMS - World Register of Marine Species (2021) Oniscidea. http://www.marinespecies.org/ aphia.php?p=taxdetails\&id=146505 [Accessed on 30 August 2021]. 


\section{Supplementary online material}

1. Video on YouTube. Xangoniscus lapaensis sp. nov. locomotor behavior in the Gruna da Lapa. https://www.youtube.com/watch?v=jFZXOb7BAdg

2. Video on YouTube. Xangoniscus loboi sp. nov. moving against the water flow in a small waterfall. https://www.youtube.com/watch?v=ZOwsvT_9gjA

3. Video on YouTube. Xangoniscus loboi sp. nov. locomotor behavior in a travertine pool on Gruna da Pingueira II. https://www.youtube.com/watch?v=iuGvySw4SV0

4. Video on YouTube. Xangoniscus loboi sp. nov., copula. https://www.youtube. com/watch?v=u2_AK_PfMHs

5. Video on YouTube. Xangoniscus loboi sp. nov., copula. https://www.youtube. com/watch? v=yL1PVQHz7OY

6. Video on YouTube. Xangoniscus loboi sp. nov., foraging and interacting behaviour. A https://www.youtube.com/watch?v=xQxKHrb80kM 